\title{
İlk Türk romanlarına getirilen ilk akademik eleştiriler üzerine
}

\section{Elif TÜRKER GÜMÜŞ}

\begin{abstract}
APA: Gümüş, E. T. (2019). İlk Türk romanlarına getirilen ilk akademik eleştiriler üzerine. RumeliDE
\end{abstract} Dil ve Edebiyat Araşttrmaları Dergisi, (15), 116-127. DOI: 10.2900o/rumelide.580483

\section{$\ddot{O} \mathbf{z}$}

Türk edebiyatında "roman” türünün ilk örnekleri 19. yüzyılda görülür. Bu ilk örnekler, nesir alanında yalnızca tahkiye usulünü tanıyan bir topluma mensup kişilerin kaleminden çıkmıştır. Dolayssıla Batı'dan "taklit” yoluyla alınan bu ilk örnekler, geleneksel olanla "yeni” arasında bir konumda kalarak okurunu bulmaya çalışmıştır. Bu evre atlatılınca türün tanınması / anlaşılması yolunda işlevli tartışmalar yürütülmüştür. Oysa ilk ürünleri Osmanlı Devleti’nin son dönemlerinde verilen "roman" türüne dair erken Cumhuriyet Dönemi’nde getirilen ilk akademik eleştirilerde, "roman" bağlamında yürütülen tartışmalar göz ardı edilerek ilk ürünlerin "kötü bir taklit”ten ibaret olduğu yolunda yorumlar yapılmıştır. Fakat bu yorumlarda bulunan araştırmacılar bir "roman" tanımı yapmadıkları gibi ilk örneklerdeki eksikliklerin de neler olduğu yolunda aydınlatıı tespitlerde bulunamamışlardır. Eleştirilerin içeriğinden anlaşıldığına göre, Batı edebiyatlarında dahi geç gelişmiş roman türünün en başarılı örnekleri ile Türk edebiyatındaki ilk örnekleri karşılaştırmak gibi akademik bir hataya düşmüşlerdir. Bu çalışmada ilk örnekleri veren yazarların "roman" görüşlerinin yanı sıra, ayn dönemde yürütülen edebiyat tartı̧malarından örnekler verilerek söz konusu yorumların değer düşürücü bir amaç güttüğü ileri sürülecektir.

Anahtar kelimeler: İlk Türk romanları, batılılaşma, taklit, tartışmalar, eleştiri.

\section{On the first academic critiques of the first Turkish novels}

\begin{abstract}
The first examples of the novel genre in Turkish literature are seen in the 19th century. These first examples are written by the authors who only know traditional narration besides poem tradition. Hence these examples which are imitated from French literature tried to find their own reader by remaining in a position between traditional and new. When this period is over, effective discussions on acknowledgement / understanding of the novel as a genre was initiated. The first academic critiques which took place in the early Republic Period described the first novels in the last period of Ottoman as 'a bad imitation'; ignoring the discussions on "novels" in that period. Moreover, in these critiques the academicians neither give a clear definition of 'novel', nor explicitly state what the deficiencies are in these first examples. As we understood from the context of these critiques an academic mistake is made by making comparisons of the first Turkish novel examples to the most successful examples of French novel which are developed lately even in French literature. In this research examples from Ottoman authors' views and the novel discussions in this period will be given in order to show the relevant academic interpretations aim to degrade these novels.
\end{abstract}

Keywords: First Turkish novels, westernization, imitation, discussions, critique. o000-0002-0066-657X [Makale kaylt tarihi: 10.05.2019-kabul tarihi: 16.06.2019; DOI: 10.29000/rumelide.580483] 


\section{"Roman" nedir?}

Edebiyat söz konusu olunca "tanım" meselesi her zaman bir sorun yaratmaktadır. Zira "tanımlamak" sınırları çizmektir ve o sınırın dışında kalan ya da o sınırı aşan her bir yeni üretime yeni bir isim vermek, yeni bir tanım yapmak, yeni sınırlar belirlemek gerektiğinden sonsuz bir döngüye hapsolmak kaçınılmazdır. Walter Benjamin bu döngüyü, "büyük yapıtlar" parantezinde toplayarak açılı̆ğa kavuşturuyor: "Edebiyatta bütün büyük yapıtların ya yeni bir tür kurduğu ya da bir eskisini ortadan kaldırdığı söylenir ki doğrudur; başka bir deyişle bütün büyük yapıtlar özel vakalardır” (Benjamin, 2006, s. 101). Fakat burada yine bir tanım meselesi giriyor işin içine, "büyük yapıt" nedir? Edebiyat, tanımlardan hoşlanmazken, edebiyat araştırmacıları, nesnel olma gayreti gösterdikleri için tanımlarla hareket etmek durumundadırlar. Bu hâlde de tanımların keskinliği meselesi giriyor işin içine. Tanım, ne kadar genel olursa, o denli esnek olacak ve dolayısıyla Benjamin'in belirttiği türde "büyük yapıtlar" kapsayacak ya da kapsamayacaktır ve fakat çok da büyük olmayan yapıtları kucaklayabilecek, dolayısıyla sınırlarını da gerektiğinde genişletebilecektir.

Bu bağlamda, tanımında belki de en zorlanılan edebiyat yapıtlarından biri olan "roman" türüne getirmek isterim sözü. Hikâyenin hangi noktadan sonra romana dönüştüğü ya da "uzun hikâye" ile "roman" arasında nasıl bir ayrım yapıldığı, yoksa yapıtın türüne yalnız o metni üreten kişinin mi karar verebileceği soruları hâlâ tartışmalıdır. Şimdi vereceğim iki ayrı roman tanımı tartışmanın sebebini daha belirginleştirecektir. İlki, Türk Dil Kurumunun hazırladığı Türkçe Sözlük'e ait: "İnsanın veya çevrenin karakterlerini, göreneklerini inceleyen, serüvenlerini anlatan, duygu ve tutkularını çözümleyen, itibarî veya gerçek olaylara dayanan uzun edebiyat türü” (Parlatır ve diğerleri, 1988, s. 1864). İkinci tanım ise, Oxford Advanced Learner's Dictionary'e ait: "Karakterlerin ve olayların genellikle hayalî olduğu, bir kitabı tamamlayacak uzunluktaki hikâye” (Wehmeier, 2000, s. 867).²

İlk tanım, detay verdiği için hatalı ve eksiktir. İyi ihtimalle roman türüne ait alt türlerden birinin tanımı olabilir. Bu tanımdaki hiçbir unsuru barındırmayan ama pekâlâ roman kabul edilen pek çok örnek sıralanabilir: Bin Hüzünlü Haz, Tristram Shandy, Dağ Yolunda Karanlık Birikiyor vs. Ya da tersinden bakalım, bu tanımdaki özellikleri barındırmayan "uzun edebiyat türü”ne ne ad verilmeli o hâlde? Tabii ondan evvel "uzun edebiyat türü”nden kastedilenin ne olduğunu anlamak gerekir.

İkinci tanım ise, yukarıda sözünü ettiğim biçimde esnetilebilecek, dolayısıyla Benjamin’in sözünü ettiği “büyük yapıt”n rahatlıkla ayırdına varılabilecek bir zemin sunmaktadır. Oxford Sözlüğü’nün verdiği tanım, bugün disiplinler arası ya da türler arası diye adlandırılagelen yaklaşımları da kapsar durumdadır. İlk verdiğim "roman” tanımının Türkçe Sözlük'e ait olması ve hatalı olması tesadüf olmamalı. Zira "roman" türünün Türk edebiyatındaki ilk örneklerinden bugüne varıncaya dek geçirdiği evrelerde, işlevli bir "roman” tanımı yapılamadığı için hep bir uzlaşmazlık söz konusudur. İlk örneklerin görüldüğü "Tanzimat edebiyatı" diye adlandırılan o ilk dönemdeki "roman” tartışmalarında da tanım sorunu göze çarpar. Bu dönemin yazarları yeni bir isimlendirmeden kaçınarak Arapçadan dile giren ve aşina oldukları bir isimle kavramı karşılamak isterler: "hikâye”. Orhan Okay’ın sözleriyle devam edelim:

"Namık Kemal kendi roman İntibah için "hikâye" dediği gibi Ahmet Mithat Efendi de Letâif-i Rivâyât serisinde çıkan ve aralarından iki yüz küsur sayfa tutan, hiç olmazsa hacimce roman çapındaki eserleri için bile "hikâye" adın vermektedir. Hatta Hasan Mellâh, Hüseyin Fellâh gibi her biri geniş hacimli macera romanları olan kitaplarını da "Hikâye Gözü" adını verdiği bir seri içinde yayımlamıştır. 1886-1887 yıllarında Beşir Fuad ve Menemenlizade Tahir arasında başlayıp araya Muallim Naci’nin, Recaizade Ekrem'in, Namık Kemal'in ve Fazh Necib’in de karıştı̆̆

\footnotetext{
$2 \quad$ "A story long enough to fill a complete book, in which the characters and events are usually imaginary." Oxford Advanced
} Learner's Dictionary. A S Hornby. Edited by Sally Wehmeier. Oxford University Press, 2000. 
münakaşalar sırasında da bu kavramlar için her iki terim birbirinin yerine kullanılmıştır. Halid Ziya 189o'dan sonra yayımladığı, romanın tarihi ve gelişmesi hakkında önemli bir inceleme ve teori eseri olan Hikâye adlı kitabında romandan hâlâ "hikâye" diye bahsetmektedir." (Okay, 2016, s. 103)

Orhan Okay'ın altını çizdiği bu durum Halit Ziya için bilinçli bir tercihtir. Henüz 23 yaşındaki Halit Ziya, İzmir'de çıkardığı Hizmet gazetesinde ilk tefrikasını yaptığı bu metnin "Mukaddime"sinde tercihini şu sözlerle açılar: "Edebiyat-ı Osmaniyede mazharı olduğu mevki-i mühimmi ihraz edemeyen aksam-ı edebiyattan biri de ecnebi bir kelime altında zikretmekten ise Osmanlı lisanına hürmeten 'hikâye' namını vereceğimiz kısm-ı edebîdir" (Uşaklıgil, 2017, s. 11). Halit Ziya'nın bu sözlerinden onun "roman" türünü tanımadı̆̆ı değil, "roman” türünü yerlileştirme gayesinde olduğu anlaşılmalıdır. Ahmet Mithat Efendi ise Halit Ziya'nın bu tercihini uygun bulmadığını "Romanlar ve Romancılık" başlıklı yazısındaki şu sözlerle dile getirir: "Osmanlı lisanına hürmeten romana mutlaka 'hikâye' namını vermek derecesinde lisan mutaassıbı görüldüğünden böyle kafalarımıza denk olmayan adamla sözleşebilmek dahi güçse de intikadatının şimdiye kadar manzurumuz olan kısmı üzerinde birkaç söz söylemekten hasbe's-sınaa kalemimizi geri alamadık" (Ahmet Mithat Efendi, 2016, s. 260). Bu sözlerin ardından Halit Ziya'nın roman sanatından beklentilerinin karşılanamadığı iddiasına, kendi roman tanımı üzerinden, o güne kadarki roman çalışmalarından, roman tercümelerinden örneklerle karşılık verir.

Oysa roman sanatının ilk örneklerine dair yürütülen ilk akademik araştırmalarda, roman sanatının Türk edebiyatındaki ilk örneklerini veren ve en bilinen isimlerinin etkin rol oynadığı tartışmalar göz ardı edilmiş ve roman sanatının Batı romanını taklitten öteye geçemediği için başarısız kaldığı ileri sürülmüştür. "Roman" Osmanlı toplumunda doğan bir tür olmadığı için onun Batı'dan taklit yoluyla alındığını bildirmek eleştiri sınırları içine dâhil edilemez. Zira bu, roman sanatı neden Osmanlı Devleti’nde doğmadı, demek gibi herhangi bir amaca hizmet edemeyecek bir sav olarak kalır. Türk edebiyatında "roman" türünün gelişimine dair yapılması gereken, o ilk örneklerin, dönemin tartışmalarıyla birlikte neye dönüştüğünü, neye hizmet ettiğini araştırmak olmalıdır. O dönemin ürünleri eleştirilecekse de anakronizm tehlikesine düşmeden bir "roman" tanımı yapıldıktan sonra dönemin ürünlerinin hangi sebeplerle bu tanıma uymadığı ve roman sanatına bir hizmeti olamadığı ya da varsa zararlarının neler olduğu bildirilmelidir. Bu çalışmada tanım yapılmadan eleştiri yapılmasının yarattığı sorunlar tartışmaya açılacaktır. Bu bağlamda, bir makalenin sinırlılıkları dahilinde ele alınabilen birkaç çalışma masaya yatırılacak ve eksik yanları tespit edilmeye çalışılacaktır.

\title{
İlk Türk romanlarının kaynakları sorunu
}

Türk romanının ilk ürünleri hakkındaki ilk akademik çalışmalardan birini gerçekleştiren Güzin Dino şöyle diyor:

\begin{abstract}
“Arap, Fars yazınının etkisinde gelişen Türk yazını, XIX. yüzyıla kadar; ilkçağ Yunan-Latin örneklerinden habersiz kalmıștır. Unutmamahdır ki, yenilik getiren ilk Osmanl yazarlarmın Batı kültürüne yönelişleri sistemli bir biçimde olmamıştır; biyografyaları da, çevrilmek için seçilen yapıtlar da, düşüncelerinde ve seçtikleri kitaplarda tam bir karmaşıklk ve seçmecilik (eklektizm) içinde olduklarını gösterir. Klasik humanizma, romantizm ya da ağlamakh duygusallık, bir arada benimsenir ve somut, kesin kavramlar getirilmez Türk yazarlarm bilgilerine. Corneille, Hugo, Dumas (baba ve oğul) ya da Shakespeare’i Osmanl yazarı eşönemde görerek beğenir; çünkü onlar için yazında ve tarihte gelişim kavramını henüz kesin bir anlamı yoktur. Batıl kaynaklar ve Batı, farkhlaşmamış bir bütün olarak, türlerin ulusal özelliklerinin gelişimi dışında göz önünde tutulur." (Dino, 1978, s. 35).
\end{abstract}

Türk romanı, deneysel boyutta kalsaydı, birkaç örnekten fazlası verilmeseydi Güzin Dino tespitinde haklı olabilirdi. Ayrıca Batı kültürüne yönelişin sistemli olmadığı iddiası da Lâle Devri’nden itibaren 
görülen yenilikler göz önünde tutulunca yanlışlanabilir. Nitekim İlber Ortaylı "Türkiye'de Klasik Çağın Algılanması” adlı makalesinde Dino’yu yanlışlıyor ve diyor ki, “17. yüzyılın hepimizin tanıdığı Kâtip Çelebi'si 'İrşad'ul Hayara ilâ Tarih-ül Yunan ve Rum ve Nasara', yani 'Yunan Rum ve Hıristiyanların Tarihleri Üzerine Hayırlı İrşadlar, Uyarılar’ adlı bir risalesinde Yunan, Roma medeniyetinden bazı özgün terimleri ve tabirleriyle bahsetmektedir. [...] Aristoteles'in hepimize malûm, devr-i daiminden bahseder" (Ortayll, 1996, s. 374. http://acikarsiv.ankara.edu.tr/browse/2691/3487.pdf?show 07.05.2019). Ortaylı, Hüseyin Hezarfen'in de "Tarih-i Devlet-i Rumiye" adında bir eser yazdığından fakat Kâtip Çelebi'ninki kadar başarılı olmadığından söz ediyor. Ayrıca Ortaylı, 19. yüzyıldaki değişimlerin doğru okunabilmesi için 18. yüzyıldaki değişikliklere bakılmasının zaruri olduğunu dile getiriyor ve o dönemin kültür hayatındaki gelişmeler hakkında şunları söylüyor:

\begin{abstract}
“18. yüzyıl başlarında Osmanlı İmparatorluğu artık Batı Avrupa’nın tesirlerine açıktı. Bazı eğitim kurumları kendi (tıb, mühendislik gibi) eğitimleri için tercümeler yapıyor, ecnebi öğretmen getiriyordu. Barok zevk Türkiye'ye girmişti. Bu dönemde klasik dünyaya hayran bir grup Osmanh okumuşu da vardı. Örneğin İstanbul'da bulunan Eflak beyinin oğlu Dimitri Cantimir, herkesin bildiği gibi batı ve doğu dilleri ve klasik dillerde derin bir bilgi sahibiydi. Osmanl tarihi ve Türk musiki sistemi üzerine kalıcı eserleri vardır. Bundan başka [...] Padua'da tahsil gören Fenerliler'den Mavrokordato kardeşler İtalyanca, Latince ve eski Yunanca üzerinde bilgi sahibi ve Aristoteles yorumcularıydılar. Onların yanında Latin kültürüne vâkıf Nefiyoğlu diye bir Türk soylusu, daha ilginci Galata kadısı yani yüksek rütbeli bir Müslüman Türk hukukçu "Yanyal Hoca" diye bilinen Mehmet Esat Efendi vardr. Bu zat, kariyerini terk etmişti ve bir Macar muhtedi olan İbrahim Müteferrika'nın matbaasında mürettib olarak çalışıyordu. Rumca biliyordu. Eski Yunanca öğrenmiş ve Latince'yi de bu muhitte tahsil etmişti.” (Ortayl, 1996, s.376-377. http://acikarsiv.ankara.edu.tr/browse/2691/3487.pdf?show 07.05.2019).
\end{abstract}

Ortaylı'nın verdiği bilgilerden anlaşıldığına göre, Osmanlı edebiyatındaki Avrupa etkisinin kaynaklarını 19. yüzyılda değil, bir yüz yıl kadar öncesinde aramak gerekir ki, 19. yüzyılda ilk örnekleri görülen türler hakkında doğru yargılara varabilelim. Yine Ortaylı'nın verdiği bilgiye göre, 19. yüzyllda söz konusu Latin-Yunan kaynakları daha etraflıca ele alınmış, Nabizade Nazım, Şemseddin Sami, Mustafa Tevfik gibi isimler, mitoloji üzerine risaleler yazmışlardır. Hatta bunlardan Şemseddin Sami’nin "Esatir" $\begin{array}{lllllll}\text { risalesi iki baskl } & \text { yapmıştır. } & \text { (Ortayll, } & 1996, & \text { s. } & 374 .\end{array}$ http://acikarsiv.ankara.edu.tr/browse/2691/3487.pdf?show 07.05.2019). Buradan hareketle, Güzin Dino’nun kastettiği biçimde bir kesin kantt getirmeme durumu söz konusu değildir, denebilir. Aksine, Osmanlı aydınları, bir arayış içine girmiş, bu arayış için Batı romanının merkez aldığı kaynakları inceleme / öğrenme yoluna gitmiştir. Fakat bu noktada Güzin Dino yalnız değildir. Jale Parla da, Dino gibi düşünmekte ve Osmanlı edebiyatının üstünde yükselmeye çalıştığı temelleri zayıf/eklemli bulmaktadır. Parla diyor ki:

"Yenilikçi” ilkelerin tümünü geleneksel kültürel normlar çerçevesinde, hatta bu normların terimlerine "tercüme" ederek tanımlamaya özen gösteriyorlardı. Bu, İmparatorluğun ahlâk, İslâm düşün ve hukuku alanındaki temellerinin pekiştirilmesi ve Batidan alınacak bir dizi teknik gelişmenin bu ana halkalara eklemlenmesi anlamına geliyordu. Başka bir deyişle, yenilik fikrinin ardında biçimlendirici, yoğurucu, belirleyici bir Osmanl kültürünün mutlak egemenliği vardı. Üstelik bu kültürün üstünde yükseldiği epistemolojik temel, adapte edilecek Batı kültürünün üzerinde yükseldiği epistemolojik temele taban tabana zıttı. Romanın çıktığı 1870 'li yıllarda henüz hiç kimse bu epistemolojik karşıtlğ̆n bilincinde gibi görünmüyordu. Beşir Fuad ve ondan sonra Recaizade Ekrem dişinda.” (Parla, 2004, s. 13).

Yine Ortaylı'dan destek alarak Jale Parla’nın iddialarının geçersiz olduğunu ileri süreceğim. Ortaylı, 19. yüzyılda Yunan ve Latin kaynaklarına yönelik eserler için, "Bu eserler, 19. yüzyllda fikir dünyamızda, Osmanlı tarihinin dışına da çıkıldığını gösteriyor” diyor ve ekliyor:

"Yani birtakım Osmanl münevverleri, fikir adamları, artık Osmanl tarihinin içtimâ̂, hukuk̂̂, kültürel köklerini aramakta ve bunun tartışmasın yapmaktadır. Aslında bunun klasik dünya 
düşüncesiyle ilgisi yoktur. Fakat buradaki tavirda bir Türk klasizmi vardır. Meselâ Ahmet Midhat; Bizans eski Yunan'la alâkası olmayan bir devlettir ve bu devletin tarihi ve bu cemiyetin âdetleri öğrenilmeden Osmanl anlaşllamaz, der.” (Ortayl, 1996, s. 374-375 http://acikarsiv.ankara.edu.tr/browse/2691/3487.pdf?show 07.05.2019)

Burada, Ahmet Mithat Efendi’nin sözleri ilginçtir. Fakat önemli olan nokta şu: Ahmet Mithat gibi "gelenekçi” biri bile Batı'daki örnekler gibi kültürel bir kök aramaktadır. Ahmet Mithat Efendi hakkında emin olduğumuz yargılardan biri, onun Batı hayranı olmadığıysa eğer, Bizans ile Osmanlı arasında kültürel bir birliktelik kurmak istemesinin altında, Batılılaşma merkezine oturtulacak bir sebep olmalıdır. O hâlde, Berna Moran’ın şu tespitine de soru işareti ile yaklaşmak gerekir:

“Biliyoruz ki bizde roman, Batı'da olduğu gibi feodaliteden kapitalizme geçis döneminde burjuva simıfinın doğuşu ve bireyciliğin gelişimi surasında tarihsel, toplumsal ve ekonomik koşullarm etkisi altında yavaş yavaş gelişen bir anlatı türü olarak çımadı ortaya. Batı romanından çeviriler ve taklitlerle başladı; yani Batılılaşmanın bir parçası olarak.” (Moran, 1983, s. 9).

Öncelikle, Berna Moran’ın sözünü ettiği ve sürekli tekrar edilen "Batılılaşma” ifadesinin ne anlama geldiğine bakalım. Şerif Mardin şöyle izah ediyor: “Osmanlı İmparatorluğu’nda başlayıp Cumhuriyet Türkiye'sinde yeni boyutlar kazanan, Batı Avrupa'nun toplumsal ve fikirsel bileşimini erişilmesi gereken bir hedef olarak gören yaklaşım" (Mardin, 2007, s. 9). Batı Avrupa'nın "toplumsal ve fikirsel bileşimini” keşfetme süreci 18. yüzyıla dayanıyor, oradan 19. ve 20. yüzylla ve hatta günümüze kadar devam etmesini göz ardı ettiğimizde Moran haklıdır, diyebiliriz. Oysa biliyoruz ki, Batı'daki kültürel gelişmeleri takip eden aydınlar, roman sanatının gücünü de keşfetmiş ve böylece "birey" meselesine değinir hale gelmişlerdir. Bu noktada, Berna Moran’ın ileri sürdüğü gibi, alt ve üst sınıflar arasında gözle görülür bir kopukluk olmadığını, aksine o zamana kadar var olan kopukluğu gidermek için çaba gösterildiğini Şinasi'nin Tercüman-ı Ahval'e yazdığı “Mukaddime”de şu şekilde görüyoruz:

\begin{abstract}
"İmdi işbu gazete ahval-i dâhiliye ve hariciyeden müntehap bâzı havadisi ve maarif-i mütenevvia ile sair mevadd-i nâfiaya dair mebahisi neşr-ü beyana vasita olacağından nâş̧î, Tercüman-ı ahval ünvan ile tesmiye olunmak münasip görüldü. Ta'rife hâcet olmadığı üzre kelâm, ifade-i meram etmeğe mahsus bir mevhibe-i kudret olduğu misillû, en güzel icad-i akl-ı insanî olan kitabet dahi kalemle tasvir-i kelâm eylemek fenninden ibarettir; bu itibar-i hakikate mebnî, giderek, umum halkın kolaylıkla anlayabileceği mertebede işbu gazeteyi kaleme almak mültezem olduğu dahi makam münasebeti ile şimdiden ihtar olunur.” (İbrahim Şinasi, 2011, s. 114)
\end{abstract}

Bu “Mukaddime”de Şinasi’nin örtük bir biçimde verdiği birtakım mesajlar olduğu açık. Öncelikle, Şinasi gazetenin bir nüshasının Saray’a gönderilceğini söyleyerek sözlerine devam ediyor. Gazetenin Saray'da okunacak olması, yazarlara otosansür uygulatan bir mekanizma olsa gerek. İkinci husus, Şinasi, gazetenin adını açıklama ihtiyacı görüyor. Yine aynı otosansür gerekçesiyle olmalı. Çünkü "Tercüman-ı Ahval" muhalefet kokusu veren bir isim. Şinasi, önlemini alıyor. Bunların her birini, son sözlerinden çıkarıyorum. "İnsan aklının en güzel icadı olan söz söyleme sanatıyla herkesin anlayabileceği bir dilde yazacaklarını” söylüyor. Burada, Şinasi'nin “akıl” vurgusu yapması, Tanzimat romanları için söylenegelen bireycilik sorunsalını ortadan kaldırıyor bana kalırsa. Batı romanını taklit eden Türk romanında akıl ve psikoloji unsurlarının eksikliğinden söz edildiğine göre Batı romanını oluşturan temel unsurların akıl ve psikoloji olduğunu çıkarabiliriz. Bu ikisi birbirinden pek de ayrılamasa bile, romandaki bireyden ya da karakterden söz edildiğinde, roman kahramanının tek boyutlu mu üç boyutlu mu olduğunu göstermesi bakımından işlevlidir. Batı romanında da "birey"den söz edilirken kastedilen "gerçekçilik”tir çünkü. Karakterin gerçekçi olabilmesi için de onun akla ve ruhsal bir evrene ihtiyacı vardir. 
Ian Watt, Romanın Yükselişi adlı kitabında, roman sanatını Defeo, Richardson ve Fielding'le başlatarak, "bugün kullandığımız 'roman' ('the novel') terimi[nin] ancak on sekizinci yüzyllın sonlarına doğru tam olarak yerleş”tiğini söylemektedir (Watt, 2007, s. 10). Bu tarih, Osmanlı edebiyatında romanın görülmeye başladığı tarihin o kadar da geç olmadı̆̆ını gösterir bize. Diğer taraftan Watt, "Kısaca değinmek gerekirse, roman tarihçileri on sekizinci yüzyıl başı romancılarını önceki kurmaca yazarlardan ayıran temel karakteristik özelliğin 'gerçekçilik' olduğunu düşünmüşlerdir” demektedir (Watt, 2007, s. 10). Türk romanının ilk örneklerini verenlerden Namık Kemal de aynı görüşü benimsemiştir. Namık Kemal, Ahmet Mithat Efendi'den farklı olarak hâlihazırdaki edebiyat geleneğini "gerçekçi” olmadığı iddiasıyla reddeder. Namık Kemal, "romandan maksat güzerân etmemişse bile güzerânı imkân dahilinde olan bir vak'ayı ahlâk ve âdât ve hissiyât ve ihtimalâta müteallik her türlü tafsilâtiyle beraber tasvîr etmektir. Romanlara nadiren mevcudât-i ruhaniye (insanüstü mevcutlar) karıştırıldığı vardır. Lâkin o türlü hayallere ne fikir ile müracaat olunduğu meselenin tasvirinden bedâhetle meydana çıar" sözleriyle 18. yüzyll sonunda ortaya çlkan "gerçekçi" roman görüşünü benimsemiş ve bu yolda roman yazmaya çalışmıştır. (Namık Kemal, 1978, s. 347). Fakat Ahmet Hamdi Tanpınar, Namık Kemal'in ahlak anlayışı ve "bilgisizliği" sebebiyle roman kişilerinin kendilerine bir alan bulamadıklarını ileri sürer (Tanpınar, 2001, s. 400). Dolayısıyla da romanları başarısız, Namık Kemal’i de yeteneksiz bulur. İntibah, roman sanatı açısından, "gerçekçilik"ten ne anlaşıldı̆̆ı göz önünde bulundurularak değerlendirilmesi gereken bir romandır oysa. Ayrıca Namık Kemal de "Celal Mukaddime"sinde İntibah'ta yapmak istediklerini "fikdan-ı istidat” sebebiyle gerçekleştiremediğini özeleştiri yaparak kabul etmektedir. (Namık Kemal, 1978, s. 348). Bu açıdan, Namık Kemal'in romanının "gerçekçilik" bağlamında nasıl bir hizmeti olduğuna bakmak gerekir.

İntibah, didaktik bir roman olabilir, Divan edebiyatından gelen söyleyiş kalıplarını içeriyor olabilir, Tanpınar'ın iddia ettiği gibi Dumas Fils'in La dame aux Camelias'sından esinlenmiş de olabilir. Peki, Mustafa Nihat Özön'ün, Türkçede Roman adlı kitabında tespit ettiği geleneksel hikâye kalıplarından ayrı bir meseleye değiniyor mu? "Hançerli Hanım Hikâyesi" ile arasında bir fark var mı? Ya da "Hançerli Hanım Hikâyesi” ile Kamelyalı Kadın arasında bir yerde duruyorsa bile bu, Türk edebiyatı için yeni bir türden yani “roman"dan söz etmeye yetmez mi?

Güzin Dino, Tanpınar'ın aksine, "Namık Kemal'in kendi kişilerini tanıtırken, derinlemesine bir ruhsal gelişmeyi denemiş ve böylece kendinden önce gelenlerin yenilik çabalarına karşın bir türlü kurtulamadıkları tek boyutlu örnek tiplerin ötesine geçmiş olması"nı önemli bulsa da Namık Kemal'in romana "aklı", "psikolojiyi" dahil etme çabasını yetersiz bulur (Dino, 1978, s. 63). Romanda eksik bir taraf vardır Dino'ya göre. Tanpınar da, Namık Kemal’in şiddetle karşı çıktığı eski geleneği romanına dahil etmesinden rahatsızlık duyar (Tanpınar, 2001, s. 405). Ona göre Namık Kemal'de "hikâyeci dehası" eksiktir.

İntibah'ın Kamelyah Kadın'ın taklidi olduğunu düşünelim ve "gerçekçilik açısından söz konusu romana bakalım. Evet, romanda ruhsal meseleler derinlemesine işlenmiştir fakat, teknik açıdan "gerçekçi" olmayan bir durum vardır. Armand adlı genç adam, ölecek kadar hasta olmasına rağmen Marguerite ile ilişkisini tüm detaylarıyla hiç ara vermeden anlatır; hikâyesi bitince de iyileşir. Burada eserin değerini sorgulamak niyetinde değilim kuşkusuz. Velev ki Namık Kemal, Kamelyah Kadın'ı taklit etti; taklit ettiği örnek de "gerçekçilik" bağlamında o kadar da gerçekçi olmayan bir kurguya sahiptir. Ian Watt, "[r]omanın biçimsel uzlaşımlardan yana fukaralığı, gerçekçi olabilmek için ödediği bir bedeldir" sözleriyle hem Dumas Filss'i hem de Namık Kemal'i kurtarır (Watt, 2007, s. 14). Fakat Ahmet Mithat'ı Güzin Dino'nun elinden kurtarmaya yetmez. Dino'nun hiç gizleme gereği duymadığı bir Ahmet Mithat Efendi öfkesi vardır. Tanzimattan Sonra Edebiyatta Gerçekçiliğe Doğru adlı kitabında, Ahmet Mithat 
Efendi’nin gerçekçiliği “yanlış” anlamasına, romanlarında kahramanların ruh dünyalarına dair hiçbir bilgi vermemesine karşı öfkesini, "lüzumsuz ilâve, uzatma ve sıçramaların, değil realiste sanat anlayışında, başlıca gayesi bir fikir ve şekil vahdetini temin etmek olan herhangi bir edebî mesleğe bağll, bir sanat eserinde yeri yoktur” sözleriyle dışarı atar (Dino, 1954, s. 19). Bu tavır akademik bakışın nesnelliğine şüphesiz ki zarar verir. Zira Güzin Dino en az bir örnekle Ahmet Mithat Efendi'nin hangi noktada bağlamdan koptuğunu, nereyi uzattığını ya da sözünü ettiği o sıçramaların metne hangi açıdan zarar verdiğini belirtmeliydi. O zaman ancak Dino'nun Ahmet Mithat Efendi'yi edebiyat sahasından neden dışladığına ikna olabilirdik. Bu hâliyle sadece bir öfke patlaması gibi kalıyor.

Ahmet Mithat Efendi, Türk romanın gelişmesi ve yerlileşmesi için en çok çaba sarf eden yazardır, demek abartılı olmaz sanırım. Mina Urgan, İngiliz Edebiyatı Tarihi adlı kitabında, İngiliz romanının yaratıcılarından Daniel Defoe'ya “'the most prolific writing machine known to us' (bizim bildiğimiz en bol üreten yazı makinesi)" dendiğini yazar (Urgan, 2012, s. 756). Türk romanının ilk yaratıcılarından Ahmet Mithat Efendi için de birebir aynı isimlendirilmenin kullanılması tesadüf değilse, zamanın ruhuyla ilgili bir durum olsa gerektir. Ya da, Ahmet Mithat Efendi bu ifadeyi dahi alacak kadar taklit etti Batı romancılarını. Burada, Cumhuriyet sonrası Tanzimat romanı hakkında fikir ileri süren araştırmacılar gibi değer düşürücü bir taklitten bahsetmiyorum. Bilakis, Ahmet Mithat Efendi’nin bu isimlendirmeyi taklit ettiğini kinayeli olarak kullanıyorum ama diyelim ki, istemeden doğruyu keşfettim; bu durumda da Ahmet Mithat Efendi’nin çabasının takdir edilmesi gerektiğini iddia edebilirim. Zira, söz konusu durum tesadüfse bile Mithat Efendi’nin roman sanatını ne denli ciddiye aldığını gösterir ki bunu sayısını tam olarak bilemediğimiz kadar çok eser bıraktığından anlamak güç değil. Dahası, Ahmet Mithat Efendi’nin roman sanatının ne'liği üzerine araştırma yapması ve iddialarını savunmak için kaleminin gücüne güvenmesi onun "başarısız" notuyla sınıfta bırakılmasına engel olmaya yetecek etmenlerdir. Sadece Ahmet Mithat Efendi için de geçerli değil bu durum kuşkusuz. Roman sanatının Batı'dan taklit eserlerle üretildiği şeklindeki değersizleştirmeye yönelik yaklaşımların anakronik olduğunu, o dönem Batı'da yürütülen tartışmalara koşut tartışmaların Osmanlı'da da yaşanmasına bakarak rahatlıkla söyleyebiliriz.

\section{“Gerçekçilik” tartışmaları ve değersizleştirilmeleri}

Şeyda Başlı, “Ulusal Alegori'den İmparatorluk Eğretilemesine: Osmanlı Romanında Çok-Katmanlı Anlatı Yapısı" 3 adlı doktora tezinde, Cumhuriyet sonrası gelişen Tanzimat romanı okumalarının değer düşürücü söylemine karşı çıkmakta ve gerek yazarlara gerekse romanlara karşı yargılayıcı tutum takınılmasını eleştirmektedir. Söz konusu çalışmada Başlı, Cumhuriyet sonrası geliştirilen bu değer düşürücü tavrın haksız olduğunu, meseleyi çeşitli yönleriyle ele alarak ispat etmektedir. Meselenin en can alıcı yönünü de Tanzimat romanlarının üretildiği dönemde yürütülen kuramsal tartışmalar oluşturmaktadır kuşkusuz. Zira, böylesi tartışmaların yürütülmesi; Güzin Dino, Berna Moran, Jale Parla gibi araştırmacıların ileri sürdükleri biçimde romanın bir anda ortaya çıkıvermediğini, anlamaya/ öğrenmeye çalışlan bir tür olduğunu ortaya çıkarmaktadır.

Başlı’nın ileri sürdüğü üzere, Tanzimat Dönemi'nde yürütülen kuramsal tartışmalar, Batı merkezli "gerçekçilik" sorunsalı, "klasikler" ve "taklit” meseleleri ekseninde dönmektedir (Başı, 2008, s. 105). "Klasikler"4 tartışmasının İsmail Avni ile Ahmet Mithat Efendi arasında yaşandığını berlirten Şeyda Başlı, İsmail Avni’nin, "klasik” hakkındaki görüşlerine Ahmet Mithat Efendi’nin kelimenin çok genel bir

Şeyda Başlı'nın tezi, Osmanlı Romanının İmkânları Üzerine adıyla İletişim Yayınları tarafından, 2010'da kitaplaştırılmıştır. "Klasikler" tartışması için bkz: Kaplan, Ramazan. Klâsikler Tartışması: Başlangıç Dönemi. Ankara: Atatürk Kültür Merkezi Başkanlığı Yayınları, 1998. 
anlamda kullanılması yönünde bir öneriyle yaklaştığını gösterir (Başlı, 2008, s. 106-107). Başlı’nın belirttiğine göre, Tercüman-ı Hakikat'te yayımlanan "Klasikler Meselesi Temhidat" başlıklı yazı dizisinde Ahmet Mithat klasiklerin, âdetleri de kapsaması gerektiği, romantik edebiyatın da zamanla klasik sayllayabileceğini ve böylece yeniliğini her daim sürdürebileceğini öne sürmektedir (Başlı, 2008, s. 106-107). Bunun üzerine tartışma roman bağlamında "taklit" meselesi etrafında dönmeye başlar. İsmail Avni, Fransız edebiyatının Türk edebiyatı üzerindeki etkisini şu sözlerle eleştirir:

"İmdi kendi lisan-ı maderzadımı ile enafis-i eser meydana koymak imkânı elde bir iken esasen büsbütün kendi mal mevarisleri dahi olmayan Fransız edebiyatı klâsiklerini edebiyat-ı müstakbelemize medar-ı terakki bir meşk ittihaz ederek zaten hiçbir hususta zevkimize tevafuk etmeyen Avrupa zevkinden bir fazlasın daha ahz ve iktibas arzusunda bulunmak doğru bir arzu olmasa gerekir." (Aktaran: Şeyda Başl, 2008, s. 115)

İsmail Avni ayrıca, Fransız romanının kaynakları nasıl ki, Yunan ve Latin kaynaklar araştırılarak temellendirildiyse, Osmanlı romanının da benzer bir yolla kaynaklarının araştıılması gerektiğini ileri sürer. Ahmet Mithat Efendi de İsmail Avni’nin bu görüşüne şu cevabı verir:

"Biz diyoruz ki alelumum klâsikleri tanıyalım. En lazım olanları yine en evvel başlayarak tercüme edelim. Bu meyanda kendimizin en eski klâsiklerimizi dahi nazar-ı tetebbua alalım. Onları da tecdid edelim. Sonra klâsik devrimize bir de yeni klâsik devri açmak için bunların umumunu temeşşuk edercesine taklid edelim. Taklid taklid derken onun neticesi tahkike vartr.” (Aktaran: Şeyda Başl, 2008, s. 119)

Buradan görülebileceği üzere, Ahmet Mithat Efendi’nin, roman sanatını yerlileştirmek gibi bir derdi vardır. Bunu yaparken de meseleyi her yönüyle ele almaya çalışır ki, eğitmekle sorumlu olduğunu düşündüğü okuyucusunu ikna edebilsin.

Güzin Dino’nun, İntibah’ın “Önsöz”ünden aktardığı şu sözler dikkat çekicidir:

“Şu kadar var ki Avrupahlar taklit ederken bir şeyin hakikaten taklide şayan olan yerlerini ediyorlar... Mantıkve âdâba mütabık gördükleri yerlerini misal-i imtisal etmişler, içlerinde akıldan hariç mübalağa, hiçbir şeye benzemez teşbih görmüşler ise ona ittibâ etmemişler, cinnas-ı lâfı gibi zevzeklikleri de makbul tutmamışlar. Ona binaen biz daima Avrupa lisanlarını edebiyatca gerek intihap ettikleri kavaid-i külliyeye gerek ihtiyar eyledikleri tarz-ı taklide tâ'bi olmak mecburiyetindeyiz. Çünkü gerek o kavaid-i külliye, gerek o tarz-ı taklid Avrupa'nın ahvamı heveskâranesinden çıkma bir takım hayalât değil sirf hakikat ve tamamiyle sevk-i tabiattır." (Aktaran: Dino, 1954, s. 4)

Buradan bakınca Namık Kemal’in Avrupa'nın çabasına hayranlık duyduğu sonucu rahatlıkla çıkabilir. Evet, Dino haklıdır bir açıdan, Namık Kemal Avrupa'nın gayretlerini takdir eder. Fakat ilk cümledeki "Şu kadar var ki Avrupalılar taklit ederken bir şeyin hakikaten taklide şayan olan yerlerini ediyorlar" sözlerinin öncesini merak ederek, yani Avrupa’nın neyi taklit ettiğini sorarak İntibah'ın “Önsöz” kısmına baktım. Şöyle diyor Namık Kemal: "Kuvvei-i hayal [hayal gücü] Şarkta bittabi Garbe galip olduğundan ve Avrupalılar -her fende olduğu gibi- edebiyatta dahi Hint'in, Yunan'ın, Arap'ın, Acem'in mukallidi bulunduğundan bu tarz-i hassın mucidi olmak şerefi dahi bizim ecdadımıza kalır" (Namık Kemal, 1971: 28). Ve Güzin Dino'nun üç nokta ile kestiği yerde de şu cümle yer alıyor: "İşte o kabilden olarak kendilerine bir numune-i edep bulmak için Arabın, Acem’in ve sair elsine-i kadîmenin asar-i muteberesini [eski dillerin önemli eserlerini] tercüme etmişler" (Namık Kemal, 1971, s. 28). Ve Dino'nun alıntısını kestiği yerden sonra da şunları yazıyor Namık Kemal:

Onlar nasll Arabin: 
Veya Acemin:

yollu tasavvurat-i şairane ve hakimanesini şevk ve haz ile kabul ederek lisanlarmda bu türlü şeylerin tercüme ve taklidiyle bir vüs'at-i efkâr [fikir genișliği] ve kuvve-i tahayyül [hayal kuvveti] hasıl etmişler ise biz dahi onlarn -tercümeleri meselâ Ekrem Bey gibi bazı üdebamızın neșriyatında görülen- birtakım asar-i nefiselerine [çok güzel eserlerini] taklit eder ve Şark ve Garbin fikr-i kemal ve bikr-i hayalini izdivaç ettirmeye çalışırız. (Namık Kemal, 1971, s. 28-29)

Buradan, Güzin Dino’nun daha önce alıntıladığımız, ilk Türk romancılarının Batı romanına karşı sistemli bir yaklaşım geliştirmedikleri yönündeki iddiasının geçersizleştiğini de görebiliriz. Namık Kemal bu sözleriyle Avrupa romanındaki gelişmeleri iyi incelediğini, Avrupa'nın romanda bir gelişme kaydettiğini ve kendilerinin o gelişmeden itibaren roman sanatını başlatmak durumunda olduklarını ve Batı'nın taklit ettiği Şark ile öğrenme yolunda oldukları Garp’ı roman sanatını birleştirme görevini üstlenmek gereğini açıklıyor. Fakat Güzin Dino meselenin bu yönüne eğilmek yerine, Namık Kemal’in akılcılık vurgusunun Fransız klasisizminden farklı olduğunu, Fransız klasisizminin temellerini Descartes'ın akılcılığından aldığını ileri sürüyor (Dino, 1954, s. 5). Fakat Namık Kemal’in akılcıllı̆ının Fransız klasisizminden neden farklı olduğuna bir açıklı getirmiyor.

Namık Kemal’in Descartesçı olmayan bir akıl yürütmeyle "gerçekçilik" hakkında fikir ileri sürdügünü varsayıp, Descartesçı akıl yürütmeyle "gerçekçilik" hakkında fikirlerini ortaya koyan bir başka yazara geçelim o halde. Orhan Okay5, Beşir Fuad'ın akıl yürütme biçiminin Descartesçı olduğunu ve böylece romanda gerçeklik meselesine şu sözlerle açılık getirdiğini belirtir:

\begin{abstract}
"Hikâye-nüvisin saye-i imdadına iltica edeceği hayal tabii olmak lazım gelir. Gerek tarih ve gerek roman için tab'u ahval-i beşerin âdeta haritasıdır denebilir. Tarih küçük mikyasta bir haritadır. Başhca mühim noktaları ve bunlarm beynindeki münasebat gösterir; roman ise büyük mikyasta bir plan olup nukat-ı muhtelifenin ahval-i hususiyesini daha mufassal ve muvazzah bir surette irâe eder. Müverrihin zapteylediği, vâkaadır. Romansiyenin ise gerçi muhayyel ise de vukuat-ı kesirenin tetkik ve ta'mikinden hasıl olan bir düsturu câmi olur. $O$ düstur sayesinde cemiyet-i beșeriyenin bir sımı-ı mahsusunun ahvaline dair olan mesail hallolunur. İște bence romanın vazifesi budur." (Aktaran: Okay, 2012, s. 147).
\end{abstract}

Beşir Fuad'ın, Menemenlizade Tahir Bey'le girdiği "hayaliyun-hakikiyun” tartışması etrafında hararetlenen bu "gerçekçilik" tartışmasına Ahmet Mithat Efendi de bir biçimde dahil olur. Onun esas amacı, halka roman sanatının nasıl ortaya çıktığı ve nasıl bir gelişme gösterdiğini anlatmaktır. Mithat Efendi'yi harekete geçiren ve bu alanda, Ahbar-ı Asara Tamim-i Enzar kitap yazmasına sebep olan olay, Nabizade Nazım'ın "Ravi” takma adıyla Emile Zola'dan başka bir romancı olmadığını, esas romanın realist roman olduğunu iddia etmesidir. Ahmet Mithat Efendi, Beşir Fuat hayattayken onun tarafinda, yani realistlerin safında yer alırken, Beşir Fuad'ın ölümünden sonra fikirlerini değiştirir ve "hakiki" olanın tarih olduğunu, romanın ise doğası gereği "hayali" olduğunu, "[i]smi roman mıdır? Mutlaka hayalî olacak" sözleriyle ileri sürer (Ahmet Mithat Efendi, 2003, s. 73). Bu vesileyle de Ahmet Mithat Efendi, roman sanatının kaynaklarını Doğu'da Binbir Gece Masalları'na, Batı'da İlliade ve Odyssee'ye kadar götürür; zira onun için hayalî olan tüm hikâyelere "roman" denebilir.

Avrupa'yla eş zamanlı yürütülen realizm-romantizm tartışmalarına İzmir'den bir genç yazar daha katılır. Henüz yirmi üç yaşındaki bu genç, Hizmet gazetesinde tefrika edilen yazılarını 1891'de Hikâye adı altında kitaplaştıran Halit Ziya Uşaklıgil’dir. Yazarın "hikâye"den kastettiği “roman”dır. Yabancı bir

Orhan Okay, Beşir Fuad'ın Victor Hugo'nun ölümünden bir buçuk ay sonra yazarın tenkitli bir biyografisini Türk okuruna sunduğunu belirtmekte ve “[bunun], Beşir Fuad'ın Avrupa'daki edebî ve fikrî hareketleri yakından ve süratle takip ettiğini göster"diğine dikkat çekmektedir. Okay ekliyor: "(O yıllarda Avrupa ile İstanbul arasında postanın değil telgraf haberlerinin bile günlerce gecikme ile geldiği de dikkate alınmalıdır.) Nitekim Avrupa'da bile henüz münakaşası yapılmakta olan Zola'yı ve natüralizmi de Türkiye'ye taşıması bu kanaatimizin başka bir delilidir (Okay, 2012, s. 129)." 
kelime kullanmaktansa Osmanlı dilinde kullanılan "hikâye" sözcüğünü tercih ettiğini kitabının "Mukaddime" bölümünde açıklar (Uşaklıgil, 2017, s. 11). Gelecekte Cumhuriyet sonrası eleştirmenlere "bile" kendisini beğendirebilecek bu genç yeteneğin hâlihazırdaki roman tutumuna itirazları vardır. Öncelikle, Avrupa'daki büyük yazarların (Balzac, Flaubert gibi) Türkçeye tercüme edilmemesini eleştirir. Realist yazarların değil, romantik yazarların eserlerinin tercüme edilmesini faydasız bulur. Buradan anlaşıldığı üzere Halit Ziya'nın roman anlayışını realistler şekillendirmiştir. "Hikâye bir vak'anın tasviri imiş! Hayır değil... Şimdi hikâye bir vak'anın tasviri olmaktan ziyade bir hissiyat levhası addolunuyor" sözleriyle de romandaki eksik gördüğü yönü ortaya sermektedir (Uşaklıgil, 2017, s. 15). Halit Ziya'yı ileride büyük yazar yapacak olan da bu görüşü olacaktır. Onunla birlikte Türk romanında derinlikli ve bütün bir psikoloji çözümlemesi görülecektir. Halit Ziya eleştirilerini sıralarken haksızlık etmemeye de çalışır. Ahmet Mithat Efendi’nin roman sanatı için yaptıklarını önemser fakat Mithat Efendi’nin sanatına eklenecek yeni metinlerin ortaya çlkmamasına itirazı vardır.

Halit Ziya, kitabına Ahmet Mithat Efendi'nin de Ahbar-ı Asara Tamim'-i Enzar'da yaptı̆̆ı gibi roman sanatının tarihini anlatarak başlar. Her iki yazar da roman sanatını Yunan eserlerinden başlatmaktadır. Halit Ziya, Ahmet Mithat Efendi'ye göre Yunan eserlerine daha hâkimdir. Orta Çağ romanları için her iki yazar da, olağanüstü hikâyelerin revaçta olduğunu, bu döngüyü kıranın Cervantes'in Don Qijote romanı olduğunu belirtirler. Hatta Halit Ziya, "Cervantes için 'Hikâyeye, Sokrat'ın felsefeye ettiği hizmeti gösterdi, yani yeniden hayata çıkardı' sözü pek haklıdı’ diyerek söz konusu romana dair kendi görüşünü de dile getirir (Uşaklıgil, 2017, s. 32). Buradan sonra iki kitap arasında birtakım farklılıklar meydana çıkıyor. Halit Ziya, "Ezmine-i Cedide” başlığı altında, yakın zamanda yazılan romanlardan söz ederken Ahmet Mithat Efendi, "Kurun-ı Cedide Evailinde Romancılık" başlığında, roman sanatının geçirdiği değişimden söz eder. Artık her iki yazar da kendi roman görüşünü izaha girişir. Ahmet Mithat Efendi, roman sanatının halkı eğitmeye yönelik yaklaşımlara sahip eleştirmenleri kendisine destek alırken Halit Ziya, örnek aldığı yazarları ve edebiyat akımlarını tanıtır, o döneme kadar yazdığı fakat pek de başarılı olmadığını düşündüğü romanları yazarkenki gayesini, yazma yöntemini dile getirir.

\section{Sonuç}

Tanzimat Dönemi edebiyatındaki bu kuramsal tartışmalara katılanlar ve tartışmanın boyutları daha da genişletilebilir kuşkusuz. Bu örneklerin çoğaltılabilir olması da Cumhuriyet sonrası araştırmacılarının ilk Türk romanlarına yaklaşımlarının ne kadar sorunlu olduğunun bir başka ispatıdır. Yalnızca genç Halit Ziya ile yazı makinesi Ahmet Mithat Efendi'nin "roman" sanatına dair çalışmaları objektif bir bakışla değerlendirildiğinde ilk Türk romanlarına getirilen eleştirilerin gerçeklikten uzak ve değer düşürmeye yönelik olduğu görülecektir. 20. yüzyılın ortalarındaki gelişmiş roman türüne bakarak ilk örnekleri değerlendirmeye almak ise zaten akademik bir hatadır.

Bu çalışmada, Robert P. Finn’in, “[...] Türk romanları, anlatı sanatının yetkin örnekleri değildir; bir nedeni, yazarların roman yazmadaki deneyimsizlikleri ve anlatım yetersizlikleridir” sözleriyle genelleştirilebilecek bu yaklaşımların dönemin edebiyat araştırmalarına ve tartışmalarına haksızlık edildiği savını ileri sürmek amaçlanmıştır (Finn, 1984, s. 14). Daha önce de söylediğim gibi, romanların edebiyat estetiği bağlamındaki değerleri ayrı bir alan olarak ele alınmalıdır. Fakat genel bir Türk romanının doğuşu panoraması çizilmek istendiğinde değer düşürücü yargılardan ziyade o dönem neyin, nasıl ve niçin yapıldığı daha detaylı bir araştırmayı hak edecek biçimde "yenilikçi"dir. Bu yeniliğe salt, "kötü bir kopya" anlamında "taklit" deyip geçmek edebiyat araştırmaları için güvenilir bir yorum içermemektedir. Zira günümüzde, "taklit” meselesine farklı bir açıdan hatta Ahmet Mithat Efendi’nin sözcüğü kullandığı anlamda yaklaşılmaktadır. Örneğin Terry Eagleton, Edebiyat Nasıl Okunur adlı 
kitabında "taklit” için şunları dile getirmektedir: "Yani 'başlangıçta taklit vardı'. Bir asılla, özgün bir şeyle karşılaştığımızı düşünsek bile onun da bir kopya, bir pastiş, bir taklit olduğundan emin olabiliriz" (Eagleton, 2015, s. 194). Bu bağlamda, edebiyat araştırmalarında artık yeni bir döneme girilmesi gerektiği, daha önceki yorumlara şüpheyle yaklaşılıp anakronizm tehlikesine düşmeden, dönemin tüm şartları ve çabaları göz önünde bulundurularak, ideolojilerden arınmış, mümkün olabildiğince nesnel yaklaşımlara ihtiyaç duyulmaktadır.

\section{Kaynakça}

Ahmet Mithat Efendi. (2003). Ahbar-ı Asara Tamim-i Enzar. Nüket Esen (Haz.). İstanbul: İletişim Yayınları. (Metin, 1889-1890 yıllarında Tercüman-ı Hakikat gazetesinde tefrika edilmiştir.)

Ahmet Mithat Efendi. (2016) Romanlar ve Romancilı. Edebiyat Yazılarn 1. H. Harika Durgun-Fazıl Gökçek (Haz.) İstanbul: Dergâh Yayınları. (Tercüman-ı Hakikat, nr. 2487, 5 Kânunuevvel 1887)

Başlı, Ş. (2008). 'Ulusal Alegori'den İmparatorluk Eğretilemesine: Osmanlı Romanında Çok-Katmanlı Anlatı Yapısı. (Osmanl Romanının İmkânları Üzerine adıyla İletişim Yayınları tarafından yayımlanmıştır.) Ankara: Bilkent Üniversitesi.

Benjamin, W. (2006). Proust İmgesi. Ahmet Doğukan ve diğer (Çev.) Son Bakışta Aşk. Nurdan Gürbilek (Ed.). İstanbul: Metis Yayınları.

Dino, G. (1954) Tanzimattan Sonra Edebiyatta Gerçekçiliğe Doğru: Birinci Kısım. Ankara: Türk Tarih Kurumu Yayınları.

Dino, G. (1978) Türk Romanını Doğuşu: İntibah: Sergüzeşt-i Ali Bey-Eylem ve Kurgusu-Kişilerin Yeni Boyutlar-İşlenen Temalar-Üslup. İstanbul: Cem Yayınevi.

Eagleton, T. (2015). Edebiyat Nasıl Okunur. Elif Ersavcı (Çev.) İstanbul: İletişim Yayınları.

Finn, R. P. (1984). Türk Romanı (İlk Dönem / 1872-19oo). Tomris Uyar (Çev.) Ankara: Bilgi Yayınevi.

İbrahim Şinasi. (2011). Tercüman-1 Ahval Mukaddime. Yeni Türk Edebiyatı Metinleri-3: Nesir-1 (186o1923). İnci Enginün-Zeynep Kerman (Haz.) İstanbul: Dergâh Yayınları. (Tercüman-ı Ahval, nr. 9, Teşrinievvel 22 Ekim 1860)

Mardin, Ş. (2007). Türk Modernleşmesi: Makaleler 4. İstanbul: İletişim Yayınları.

Moran, B. (1983). Türk Romanına Eleştirel Bir Bakış: Ahmet Mithat'tan A.H. Tanpınar'a. İstanbul: İletişim Yayınları.

Namık Kemal. (1971). Son Pişmanlık’ın Mukaddemesi. İntibah: Sergüzeşt-i Ali Bey. Mustafa Nihat Özön (Haz.) İstanbul: Remzi Kitabevi. (“Kemal Bey’in Bir Makalesi” başlığı ile Şark, nr.5, Mart 1881)

Namık Kemal. (1978). Mukaddime-i Celâl. Yeni Türk Edebiyatı Antolojisi II. Mehmet Kaplan ve diğer (Haz.) İstanbul: İstanbul Üniversitesi Edebiyat Fakültesi Yayınları. (Kitaphane-i Ebuzziya, 1881)

Okay, M. O. (2012). Beşir Fuad: İlk Türk Pozitivist ve Naturalisti. İstanbul: Dergâh Yayınları.

Okay, M. O. (2016). Batılılaşma Devri Türk Edebiyatı. İstanbul: Dergâh Yayınları.

Ortaylı, İlber. 1996. Türkiye'de Klasik Çağın Algılanması. Ankara: Ankara Üniversitesi Sosyal Bilimler Fakültesi Dergisi. Sayı: 1-4 C.: 51. (371-380) Erişim tarihi: 07.052019. http://www.dergiler.ankara.edu.tr

Oxford Advanced Learner's Dictionary. (2000). A S Hornby. Sally Wehmeier (Ed.) Oxford University Press.

Özön, M. N. (2015). Türkçede Roman. İstanbul: İletişim Yayınları.

Parla, J. (2004). Babalar ve Oğullar: Tanzimat Romanını Epistemolojik Temelleri. İstanbul: İletişim Yayınları.

Parlatır, İ. ve diğer. (1988). Türkçe Sözlük 1-2. Ankara: Türk Dil Kurumu Yayınları.

Tanpınar, A. H. (2001). 19uncu Asır Türk Edebiyatı Tarihi. İstanbul: Çağlayan Kitabevi. 
Urgan, M. (2012). İngiliz Edebiyatı Tarihi. İstanbul: Yapı Kredi Yayınları.

Uşaklıgil, H. Z. (2017). Hikâye. İstanbul: Dergâh Yayınları. (Metin, 1887-1888 yıllarında Hizmet gazetesinde tefrika edilmiştir.)

Watt, I. (2007). Romann Yükselişi: Defoe, Richardson ve Fielding Üzerine İncelemeler. Ferit Burak Aydar (Çev.) İstanbul: Metis Yayınları. 